\title{
Effects of Inter and Intra Row Spacing on Yield and Yield Components of Soybean (Glycine max L.) Under Rainfed Condition in North western Ethiopia
}

\author{
Yimer Abeje* \\ Technology Multiplication and Seed Research Directorate, \\ Gondar Agricultural Research Center, P.O. Box 1337, Gondar, Ethiopia \\ Tilahun Tadesse \\ Fogera National Rice Research and Training Center, \\ Crop Research Directorate, P.O. Box 1937, Fogera, Ethiopia \\ Yenus Ousman \\ University of Gondar, Department of Plant Sciences, \\ P. O. Box 196, Gondar, Ethiopia
}

\begin{abstract}
The research is financed by Sesame Business Network (SBN) Project (Sponsoring information)
Abstract

The experiment was conducted in 2016/17 cropping season under rain fed condition in Metema and Tach Armachiho districts of the Amhara regional state, Ethiopia. The treatments consisted of a factorial combination of four levels of inter row spacing $(40,60,80,100 \mathrm{~cm})$ and three levels of intra row spacing $(5,10,15 \mathrm{~cm})$. The treatments were laid out in randomized complete block design with three replications. The main effects of row and intra row spacings were significantly affecting days to $90 \%$ physiological maturity, number of branch/plants, biomass yield and grain yield/hectare. On the other hand, except harvesting index, all other parameters were not significantly influenced by the interaction effect of inter and intra row spacing. The highest biomass and grain yields were recorded at $40 \mathrm{~cm}$ inter and $5 \mathrm{~cm}$ intra row spacing. Results of the economic analysis showed that the maximum net benefit was obtained in soybeans planted with $60 \mathrm{~cm}$ by $10 \mathrm{~cm}$ inter and intra row spacing, respectively. Thus, farmers in Metema and Tach Armachiho can use $60 \mathrm{~cm}$ by $10 \mathrm{~cm}$ inter and intra row spacing respectively for mung bean production.
\end{abstract}

Keywords: Inter Row Spacing, Intra Row Spacing, Plant Density, Seed Yield

DOI: $10.7176 / \mathrm{JBAH} / 10-8-05$

Publication date: April $30^{\text {th }} 2020$

\section{Introduction}

Soybean (Glycine max L.) is one of the most important sources of edible oil and protein. Its seed contains approximately $20 \%$ oil, $40 \%$ protein and high content of minerals, particularly calcium, phosphorus and iron (Iita, 1992; Ita, 1993). Its seed oil is rich in essential fatty acids (Acikgoz et al., 2009). The total area of land under production and total volume of soybean production in Ethiopia has been growing over years. In the country, the total land under soybean production in 2013/14 growing season was 30,517.38 hectare and its productivity was 20 quintal/ha. While in 2016/17 area of land covered by soybean was 36, 635.79 hectare, which increased by $8.3 \%$ and its productivity was 22.17 quintal/ha. In Amhara region, 13,677.21 hectare of land was covered by soybean in 2016/17 during the main growing season CSA, 2017). Like many other major crops, the productivity level of soybean is very low (1.06 ton/ha) during the last ten years (Mekonnen Hailu and Kaleb Kelemu, 2014) compared to the potential yield (4-ton/ha) if improved varieties and appropriate crop management practices are used. Improper agronomic managements including limitation of sowing at optimum plant density per unit of land is one of the constraints responsible for the lowest productivity of the crop. Farmers at Metema and Tach Armachiho districts differently use narrower or wider inter and intra row spacing that might reduce yield due to competition for space, nutrients, light, $\mathrm{CO} 2$ and moisture at higher density or wastage of space at lower planting density. Therefore, the present study was undertaken to determine optimum inter and intra row spacing (planting density) for soybean cultivation at Metema and Tach Armachiho districts, Northwestern Ethiopia.

\section{Materials and Methods}

2.1. Description of the Study Area

The experiment was conducted in 2016/17 main cropping season at Metema (12 47" 38' $\mathrm{N}$ and $36^{0} 23^{\prime \prime} 41^{\prime} \mathrm{E}$, elevation $769 \mathrm{~m}$ ) and Tach Armachiho (13031' 00" $\mathrm{N}$ and 37 $17^{\prime}$ 00" E, elevation $972 \mathrm{~m}$ ) experimental stations of Gondar Agricultural Research Center, located in Northwestern Ethiopia. The average annual rainfall of Metema and Tach Armachiho is 1012.9 and $950.8 \mathrm{~mm}$, respectively. The rainy months mostly extend from June to 
September. However, much rainfall is received during the months of July and August. The mean maximum and minimum temperatures are $35.5^{\circ} \mathrm{C}$ and $20.7^{\circ} \mathrm{C}$ at Metema and $33.0^{\circ} \mathrm{C}$ and $17.6^{\circ} \mathrm{C}$ at Tach Armachiho. The soil texture at both sites were clay containing $10 \%$ sand, $28 \%$ silt and $62 \%$ clay, $0.1 \%$ total N, $2.3 \mathrm{~g} / \mathrm{kg}$ available $\mathrm{P}$ (Olsen), $0.70 \mathrm{cmol} / \mathrm{kg} \mathrm{K}+, 57.4 \mathrm{cmol} / \mathrm{kg} \mathrm{CEC}$, with soil $\mathrm{pH} 7.2$ at Metema while Tach Armachiho soil contains $19 \%$ sand, $17 \%$ silt and $64 \%$ clay, $0.1 \%$ total $\mathrm{N}, 0.9 \mathrm{~g} / \mathrm{kg}$ available $\mathrm{P}(\mathrm{Olsen}), 1.1 \mathrm{cmol} / \mathrm{kg} \mathrm{K}+, 50.5 \mathrm{ncmol} / \mathrm{kg} \mathrm{CEC}$, with soil $\mathrm{pH}$ of 6.9 .

\subsection{Treatments and Experimental Design}

Factorial combinations of four levels of inter row spacing $(40,60,80$ and $100 \mathrm{~cm})$ and three levels of intra row spacing $(5,10$ and $15 \mathrm{~cm})$ were laid out in a randomized complete block design (RCBD) with three replications. The gross plot size was $6 \mathrm{~m} \times 2.1 \mathrm{~m}(12.6 \mathrm{~m} 2)$, accommodating 15, 10, 7, and 6 numbers of rows for 40, 60, 80, and $100 \mathrm{~cm}$ inter row spacing, respectively. These made the net plot width to be 5.2, 4.8, 4 and $4 \mathrm{~m}$ for the four respective inter row spacing. Total experimental area was $18 \mathrm{mx} 36.2 \mathrm{~m}(760.2 \mathrm{~m} 2)$. Spacing $1 \mathrm{~m}$ between plots and $1.5 \mathrm{~m}$ between replications were used. During data collection and harvesting two rows (one from the left and one from the right) were excluded to avoid border effects. Finally, the biomass and grain yields were converted in to kg ha-1 base.

Seeds were planted in furrows manually at a depth of about $5-7 \mathrm{~cm}$ and all the stages of land preparation, fertilizer application, insect, disease, and weed control operations were carried out manually according to the recommendations followed in the region. Improved soybean variety named as AFGAT was used as a seeding material for the study. Diammonium phosphate (DAP) with a rate of 100kgha-1 (blanket recommendation) was applied at planting and other agronomic practices were done as per the recommendations.

\subsection{Data Collection and Analysis}

Data on plant phenology, growth parameters, yield and yield related traits were collected from the net area of each plot. All the collected data were subjected to analysis of variance following the procedure described by Gomez and Gomez (1984) using SAS version 9.0 (SAS Institute, 2001). Homogeneity of variances was tested to combine the data over the two locations using F-max ratio method as described by Bart et al. (2012) and the test was significant on parameters of days to $50 \%$ flowering, biomass yield and protein content. Thus, combined analysis was executed for the non-significant parameters but days to $50 \%$ flowering and protein content were analyzed independently for each location. Differences among treatment means were compared using the Least Significance Difference (LSD) test at 5\% level of significance.

To identify the economic optimum seed rate of soybean, economic analysis was done using the CIMMYT partial budget analysis methodology (CIMMYT, 1988). Average grain price of Ethiopian Birr (ETB) 8/kg and seed cost of ETB 10/kg was used for the analysis. It was estimated that 10-man days were needed to prepare the field and to sow the seeds. The labor cost for field preparation and planting was estimated to be ETB 50 per mandays. Following the CIMMYT partial budget analysis methodology, total variable costs (TVC), gross benefits (GB) and net benefits (NB) were calculated. Then treatments were arranged in an increasing TVC order and dominance analysis was performed to exclude dominated treatments from the marginal rate of return (MRR) analysis. A treatment is said to be dominated if it has a higher TVC than the treatment which has lower TVC next to it but having a lower net benefit. A treatment which is non-dominated and having MRR of greater or equal to $100 \%$ and the highest net benefit is said to be economically profitable.

\section{Result and Discussion}

3.1. Crop Phenology and Growth Parameters

3.1.1. Days to 5 Flowering

Days to $50 \%$ flowering was significantly influenced by the main effect of inter and intra row spacing at Metema district. On the other hand, the main effect of inter and intra row spacing at Tach Armachiho and their interaction effect at both locations were not significant. At Metema district, soybeans planted with $100 \mathrm{~cm}$ inter row and 10 $\mathrm{cm}$ intra row spacing took long days to flower (52.56 and 51.58 days, respectively) compared to other treatments, which were statistically at par to each other (Table 1). Days to flowering delayed from 50.11 to 52.56 days as inter row spacing become wider from 40 to $100 \mathrm{~cm}$ and 50.5 to 51.58 days as intra row spacing become wider from 5 to $10 \mathrm{~cm}$. Days to $50 \%$ flowering was significantly influenced by the main effect of inter and intra row spacing at Metema district. This result is in agreement with finding of Charles and Dougherty (1969); who reported that flowering delayed more at wider rows than narrower rows. These results indicated that the onset of flowering of soybeans might be progressively retarded at lower plant density by reducing intensities of interplant competition. On the other hand, Young et al. (2001) reported that plant density had no effect on days to flowering in soybean. 
Table 1. Response of days to $50 \%$ flowering to the main effect of inter and intra row spacing of soybean at Metema district.

\begin{tabular}{ll}
\hline Treatments & Days to $\mathbf{5 0 \%}$ flowering \\
\hline Intra row spacing $(\mathrm{cm})$ & \\
5 & $50.5^{\mathrm{b}}$ \\
10 & $51.58^{\mathrm{a}}$ \\
15 & $50.66^{\mathrm{ab}}$ \\
Mean & 50.9 \\
LSD $(5 \%)$ & 0.9 \\
Inter row spacing $(\mathrm{cm})$ & \\
40 & $50.11^{\mathrm{b}}$ \\
60 & $50.22^{\mathrm{b}}$ \\
80 & $50.78^{\mathrm{b}}$ \\
100 & $52.56^{\mathrm{a}}$ \\
Mean & 50.9 \\
LSD $(5 \%)$ & 1.1 \\
CV $(\%)$ & 2.1 \\
\hline
\end{tabular}

Means within a column followed by the same letter(s) are not significantly different at $\mathrm{P}=0.05$.

3.1.2. Days to $90 \%$ Physiological Maturity

The combined analysis of variance showed that the main effect of inter and intra row spacing on days to $90 \%$ physiological maturity was statistically significant $(\mathrm{p}<0.01)$. Soybean planted with smaller inter row $(40 \mathrm{~cm})$ and intra row $(5 \mathrm{~cm})$ spacing matured earlier (107.20 and 106.60 days, respectively) compared to wider spacing (80 and $15 \mathrm{~cm}$ ), which took 110 and 109.40 days, respectively. However, there was no significant difference in between 40 and $60 \mathrm{~cm}$ as well as in between 80 and $100 \mathrm{~cm}$ inter row spacing on days to physiological maturity (Table 2). This result was against with the finding of Osei and Norman (1980); who reported that maturity did not showed significant difference among inter and intra row spacing.

3.1.3. Plant Height $(\mathrm{cm})$

The combined analysis of variance showed significant difference on plant height among the main factor of intra row spacing. On the other hand, the main effect of inter row spacing and the interaction of inter row by intra row spacing had not showed significant difference in plant height. As intra row spacing becomes wider, plant height decreased significantly. The longest soybean plant $(67.10 \mathrm{~cm})$ was measured with the narrowed $(5 \mathrm{~cm})$ intra row spacing, while the shortest plant $(62.20 \mathrm{~cm})$ was measured with the wider $(15 \mathrm{~cm})$ intra row spacing, but soybeans planted with $10 \mathrm{~cm}$ and $15 \mathrm{~cm}$ intra row spacing did not show statistically significant difference $(\mathrm{P}<0.05)$ in plant height (Table 2). Decreasing the distance between plants (higher plant densities) increased the plant height significantly. This may be attributed to the highest inter specific competition for light at denser plant populations. Hassan (2015) and Sevgi et al. (2015) agreed with this result. Young et al. (2001)] also demonstrated that, plant height of soybean increased with increasing plant density. On the other hand, Biabania et al. (2008) reported that intra row spacing had not influenced plant height.

3.1.4. Number of Branches Per Plant

The main effect of inter and intra row spacing showed significant difference on number of branches per plant. Number of branches per plant varied among the main factor of both inter and intra row spacings. This significant variation resulted from density differences. Narrowed inter and intra row spacing gave significantly lower number of branches per plant, while wider inter and intra row spacing gave highest branches. It ranged from 6.7 to 7.9 branches/plant among inter row and from 6.7 to 7.8 branches/plant among intra row spacing (Table 2). Soybeans grown in low plant density conditions utilize free plant growth resources (space and plant nutrients) better due to less inter specific competition compared to denser populations. Therefore, it enabled the plant to allocate the greater dry matter content into the branches. This finding is supported by the reports of Zaimoglu et al. (2004), Cox and Cherney (2011) and Saitoh (2011). Authors, Mohammed Worku and Tessema Astatkie (2011) reported similar results based on their experiment. Other researchers, Biabania et al. (2008) and Sevgi et al. (2007) are also reported similar observations. 
Table 2. Responses of crop phenology and growth parameters of soybean to the main effect of inter and intra row spacing combined over the two locations.

\begin{tabular}{llll}
\hline Treatments & DM & PH & NBP \\
\hline Intra row spacing $(\mathrm{cm})$ & & & \\
5 & $106.6^{\mathrm{c}}$ & $67.1^{\mathrm{a}}$ & $6.7^{\mathrm{c}}$ \\
10 & $108.4^{\mathrm{b}}$ & $64.3^{\mathrm{b}}$ & $7.2^{\mathrm{b}}$ \\
15 & $110.0^{\mathrm{a}}$ & $62.2^{\mathrm{b}}$ & $7.8^{\mathrm{a}}$ \\
Mean & 108.3 & 64.5 & 7.2 \\
LSD (5\%) & 0.99 & 2.5 & 0.42 \\
Inter row spacing $(\mathrm{cm})$ & & & \\
40 & $107.2^{\mathrm{b}}$ & 63.2 & $6.7^{\mathrm{c}}$ \\
60 & $107.5^{\mathrm{b}}$ & 64.7 & $7.0 \mathrm{~b}^{\mathrm{c}}$ \\
80 & $109.4^{\mathrm{a}}$ & 65.2 & $7.2^{\mathrm{b}}$ \\
100 & $109.3^{\mathrm{a}}$ & 64.9 & $7.9^{\mathrm{a}}$ \\
Mean & 108.3 & 64.5 & 7.2 \\
LSD (5\%) & 1.1 & 2.9 & 0.48 \\
CV $(\%)$ & 1.6 & 7.1 & 9.7 \\
\hline M & & & 9.7 \\
\hline
\end{tabular}

Means within a column followed by the same letter(s) are not significantly different at $\mathrm{P}(0.05)$. DM=days to $90 \%$ physiological maturity, $\mathrm{PH}=$ plant height in $\mathrm{cm}$ and $\mathrm{NBP}=$ number of branches per plant.

\subsection{Yield and Yield Component Traits}

3.2.1. Number of Pods Per Plant and Number of Seeds Per Pod

Number of pods per plant is one of the most important yield contributing traits. Ohyama et al. (2013) reported that soybean productivity mainly depends on the number of pods/plant Number of pods per plant were not significantly affected by inter row spacing, while the effect of intra row spacing was significant. The narrowed intra row spacing gave fewer pods than wider intra row spacing (Table 3). Alireza et al. (2013) found that number of pods per plant at lower plant density was larger than that of at the higher plant density. Saitoh 2011) provided similar findings. More over Ohyama et al. (2013) found more pods at low density, which was resulted from the enhanced in branching per plant.

The combined analysis of variance showed that the main effect of inters row spacing on number of seeds per pod was significant. Lower number of seeds per pod was counted on plots where soybean was sown with $60 \mathrm{~cm}$ inter row spacing. Number of seeds per pod did not show consistent pattern among inter row spacing (Table 3 ). These findings were in agreement with findings reported by Saitoh (2011), Mohammed Worku and Tessema Astatkie (2011) and Akond et al. (2013), who reported that seeds per pod did not display large response to plant density.

\subsubsection{Biomass and Grain Yield}

The combined analysis of variance indicated that the main effects of both inter and intra row spacing, but not their interaction, significantly influenced the biomass yield. The highest biomass yield (5672.60 and $4792.40 \mathrm{~kg} \mathrm{ha-1)}$ were achieved from the narrower $(40$ and $5 \mathrm{~cm})$ inter and intra row spacing, respectively, while the smallest biomass (2930.40 and $3521.80 \mathrm{~kg}$ ha-1) were achieved from the wider $(100$ and $15 \mathrm{~cm})$ inter and intra row spacing, respectively. As presented in Table 3, biomass yield increased significantly with decreasing inter row spacing from 100 to $40 \mathrm{~cm}$ and intra row spacing from 15 to $5 \mathrm{~cm}$. The result agrees with that of other findings (Leyla et al., 2017, Mohammed Worku and Tessema Astatkie, 2011; Alireza et al.,2013). Rahman et al. 2005) reported that the biomass production of crop is closely related to the amount of solar radiation intercepted by the crop canopy. Thus, higher plant density speeds up canopy closure (when little or no incoming radiation reaches the soil surface) and increases interception of Photosynthetically Active Radiation (PAR) needed for carbohydrate production in the plants. Alireza et al. (2013) demonstrated that differences in dry matter production at various plant densities can be attributed to differences in the absorption of effective radiation in photosynthesis and to differences in the efficiency of the plants in using the light absorbed at various plant densities.

The combined analysis of variance showed the main effects of inter and intra row spacing on grain yield was highly significant $(\mathrm{P}<0.01)$. Grain yield $\mathrm{kg}$ ha-1 increased statistically with decreasing inter and intra row spacing. Grain yield of 2785.0 and $2388.2 \mathrm{~kg}$ ha- 1 were achieved from narrower (40 and $5 \mathrm{~cm}$ ) inter and intra row spacing, respectively, while the lower grain yields of 1430.6 and $1617.3 \mathrm{~kg}$ ha-1 were achieved from wider (100 and 15 $\mathrm{cm}$ ) inter and intra row spacing, respectively. But grain yield with 80 and $100 \mathrm{~cm}$ inter row spacing was not showed significant difference statistically (Table 3). The yield increases with the narrower inter and intra row spacing (higher plant density) was attributed to earlier establishment of canopy closure, greater light interception and reduction in competition of nutrient and moisture from weeds. Sevgi et al. (2007) is parallel with this finding. They illustrated that substantial grain yield increase was achieved by decreasing inter row spacing from 70 to $50 \mathrm{~cm}$, but there was no increase on grain yield by further decreasing the inter row spacing in full season soybeans. A full 
canopy of healthy leaves of soybean facilitated photosynthetic rates to be near their maximum, which helps flowers to stay on the plant and to develop into productive pods. Acikgoz et al. (2009) observed similar results and concluded that increasing plant density reduced grain yield of individual plants but increased grain yield per unit area.

Table 3. Responses of number of pods/plants, Number of seed/pods, biomass yield ha-1 and grain yield ha-1 to the main effect of inter and intra row spacing of soybean combined over Metema and Tach Armachiho.

\begin{tabular}{|c|c|c|c|c|}
\hline Treatments & NPP & NSP & BM $\left(\mathrm{kg} \mathrm{ha}^{-1}\right)$ & GY $\left(\mathrm{kg} \mathrm{ha}^{-1}\right)$ \\
\hline \multicolumn{5}{|c|}{ Intra row spacing $(\mathrm{cm})$} \\
\hline 5 & $51.3^{\mathrm{b}}$ & 2.60 & $4792.4(3.7)^{\mathrm{a}}$ & $2388.2^{\mathrm{a}}$ \\
\hline 10 & $56.1^{\mathrm{ab}}$ & 2.60 & $4025.5(3.6)^{b}$ & $2035.8^{b}$ \\
\hline 15 & $58.7^{\mathrm{a}}$ & 2.60 & $3521.8(3.5)^{\mathrm{c}}$ & $1617.3^{c}$ \\
\hline Mean & 55.4 & 2.56 & 4113.2 & 2013.8 \\
\hline $\operatorname{LSD}(5 \%)$ & 5.7 & 0.06 & 396.9 & 208.1 \\
\hline \multicolumn{5}{|c|}{ Inter row spacing $(\mathrm{cm})$} \\
\hline 40 & 53.3 & $2.60^{\mathrm{a}}$ & $5672.6(3.7)^{\mathrm{a}}$ & $2785.0^{\mathrm{a}}$ \\
\hline 60 & 58.1 & $2.50^{\mathrm{b}}$ & $4644.9(3.6)^{\mathrm{b}}$ & $2257.8^{b}$ \\
\hline 80 & 54.3 & $2.60^{\mathrm{a}}$ & $3205.1(3.5)^{\mathrm{c}}$ & $1581.7^{\mathrm{c}}$ \\
\hline 100 & 55.8 & $2.60^{\mathrm{a}}$ & $2930.4(3.4)^{\mathrm{c}}$ & $1430.6^{\mathrm{c}}$ \\
\hline Mean & 55.4 & 2.56 & 4113.2 & 2013.8 \\
\hline $\operatorname{LSD}(5 \%)$ & 6.68 & 0.06 & 458.3 & 240.3 \\
\hline $\mathrm{CV}(\%)$ & 18.0 & 4.0 & $16.6(1.99)$ & 18.4 \\
\hline
\end{tabular}

Means within a column followed by the same letter(s) are not significantly different at P (0.05). NPP $=$ number of pods per plant, $\mathrm{NSP}=$ number seeds per pod, $\mathrm{BM}=$ biomass yield and $\mathrm{GY}=$ grain yield.

3.2.3. Harvest Index (\%)

The combined analyses of variance of the interaction of inter row by intra row spacing showed significant effect on harvesting index. As indicated on Table 4, the interaction spacing of $10 \mathrm{x} 80 \mathrm{~cm}$ produced more $(56 \%)$ harvesting index, while of $80 \times 15 \mathrm{~cm}$ produced the least value $(42 \%)$. This study demonstrated that harvesting index lacks consistent increasement or decrement among the interaction of inter and intra row spacing (Table 4). Scientists reported differently based on their observation during experimentations. For instance, Aziz et al. (2005) reported that harvest index is influenced more by genetic factors; and it increases, or decreases, with an increase, or decrease, in the biological yield. On the other hand, Ohyama et al. (2013), observed that the harvest index gradually decreased with the decreasing plant density during his experimentation years.

Table 4. Response of harvesting index (\%) to the interaction effect of inter row by intra row spacing of soybean combined over Metema and Tach Armachiho.

\begin{tabular}{llll}
\hline & \multicolumn{3}{l}{ Intra row spacing $(\mathbf{c m})$} \\
\hline Inter row spacing $(\mathrm{cm})$ & 5 & 10 & 15 \\
40 & $50^{\mathrm{bc}}$ & $48^{\mathrm{bc}}$ & $48^{\mathrm{bc}}$ \\
60 & $49^{\mathrm{bc}}$ & $50^{\mathrm{bc}}$ & $47^{\mathrm{bcd}}$ \\
80 & $49^{\mathrm{bc}}$ & $56^{\mathrm{a}}$ & $42^{\mathrm{d}}$ \\
100 & $51^{\mathrm{ab}}$ & $49^{\mathrm{bc}}$ & $45^{\mathrm{cd}}$ \\
LSD (5\%) & 6.0 & & \\
CV (\%) & 11.4 & & \\
\hline
\end{tabular}

Means within a column followed by the same letter(s) are not significantly different at $\mathrm{P}=0.05$.

3.2.4. Protein Content (\%)

Evaluating the effects of inter and intra row spacing demonstrated that these factors had no remarkable effect on protein content of soybean at both locations. Even though it was insignificant, the value of the protein content was in the recommended range. It varies from 40.86 to 41.18 among intra row spacing and from 40.4 to 41.54 among inter row spacing. The result indicated that both inter and intra row spacing has not affected protein content. Leyla et al. (2017) conducted similar research and they reported similarly that significant variation was not observed among the plant densities on the protein content to different plant densities. In contrast, Moshiur et al. (2011) demonstrated that the protein content of soybean reduced with increase in plant density.

\subsection{Economic Analysis}

Even though the areas are potential for soybean production, optimum inter and intra row spacing (plant densities) of the crop and its profitability in Metema and Tach Armachiho are not identified yet. Farmers in these districts use traditional planting densities. This scenario is not economically valuable. Results of the economic analysis showed that the maximum net benefit (ETB 17548.89 ha-1) with an acceptable MRR was obtained from planting of soybean with $60 \mathrm{~cm}$ by $10 \mathrm{~cm}$ inter and intra row spacing, respectively (Table 5). Farmers may have the 
opportunity to decrease seed and labor cost and to increase soybean yield, and ultimately improve their livelihoods through adopting the appropriate planting densities and management practices. For instance, in the current study, planting of soybean with $60 \mathrm{~cm}$ inter row by $10 \mathrm{~cm}$ intra row spacing increased net benefit by $51 \%$ and $94 \%$ over soybeans planting with $60 \mathrm{~cm}$ by $15 \mathrm{~cm}$ and $100 \mathrm{~cm}$ by $15 \mathrm{~cm}$ inter and intra row spacing, respectively, which implies that increase in farmers' income with a simple improvement in crop management. The present finding demonstrated that, optimum economic plant densities of soybean are often less than densities that result in maximum yield, because of higher labor and seed costs at higher densities. This result is in line with Lee et al. (2008) and De Bruin and Pedersen (2008). De Bruin and Pedersen (2008) reported that, changes in seeding rates contributed to significant yield changes but not to changes in profitability.

Table 5. Results of the economic analysis for inter and intra row spacing of soybean combined over Metema and Tach Armachiho districts.

\begin{tabular}{|c|c|c|c|c|}
\hline TRTs & TVC (Birr/ha) & Net Benefit (Birr/ha) & Dominance Analysis & MRR (\%) \\
\hline $100 \times 15$ & 3854.27 & 8162.36 & & \\
\hline $80 \times 15$ & 4817.84 & 6805.14 & $\mathrm{D}$ & \\
\hline $100 \times 10$ & 5781.40 & 8075.05 & $\mathrm{D}$ & \\
\hline $60 \times 15$ & 6423.78 & 12454.81 & & 167.05 \\
\hline $80 \times 10$ & 7235.93 & 9604.48 & $\mathrm{D}$ & \\
\hline $40 \times 15$ & 9635.67 & 15909.72 & $\mathrm{D}$ & \\
\hline $60 \times 10$ & 9635.67 & 17548.89 & & 158.60 \\
\hline $100 \times 5$ & 11562.81 & 4015.14 & $\mathrm{D}$ & \\
\hline $40 \times 10$ & 14453.51 & 13086.20 & $\mathrm{D}$ & \\
\hline $80 \times 5$ & 14453.51 & 6100.61 & $\mathrm{D}$ & \\
\hline $60 \times 5$ & 19271.35 & 8343.94 & $\mathrm{D}$ & \\
\hline $40 \times 5$ & 28907.02 & 4093.58 & $\mathrm{D}$ & \\
\hline
\end{tabular}

TRTs $=$ Treatments, $\mathrm{TVC}=$ total variable $\operatorname{cost}, \mathrm{MRR}=$ marginal rate of return.

\section{Conclusion and Recommendation}

The current result indicated that inter row spacing of $40 \mathrm{~cm}$ and intra row spacing of $5 \mathrm{~cm}$ gave higher grain yield of soybean under rain-fed agriculture in Metema and Tach Armachiho districts. On the other hand, the present finding indicated that economically optimum inter and intra row spacing were wider than inter and intra row spacing that gave higher grain yield $(60 \mathrm{~cm}$ and $10 \mathrm{~cm}$ inter and intra row spacing, respectively). Thus, changes in seeding rates contributed to significant yield changes but not to changes in profitability due to labor and seed cost. Thus, farmers in Metema and Tach Armachiho districts can use $60 \mathrm{~cm}$ by $10 \mathrm{~cm}$ inter and intra row spacing respectively.

\section{References}

Acikgoz, E., M. Sincik, A. Karasu, O. Tongel, G. Wietgrefe, U. Oz. M. Bilgili, S. Albayrak, Z. M. Turan and A. Goksoy. (2009). Forage soybean production for seed in Mediterranean environments. Field Crops Research, $110: 3,213-218$.

Akond, A. G. M., R. Bobby, R. Bazzelle, W. Clark, S. K Kantartzi, K. Meksem and A. Kassem. (2013). Effect of two row spaces on several agronomic traits in soybean [Glycine max (L.) Merr.]. Atlas Journal of Plant Biology, 1: 18-23. doi: 10.5147/ajpb.2013.0073.

Alireza, D., Y. Mohammad, N. K. K. Hassan and Y. Esmaeil. (2013). Investigation of the effects of plant density and planting date on the quantitative and qualitative yields of two advanced soybean lines. International Journal of Biology, 5: 3, doi:10.5539/ijb. 5: 3, 37.

Azizi, M., A. Faramarzi, \& M. Abdi. (2005). Evaluation of effects of different planting dates on four cultivars of soybean in Mianeh. Journal of Agricultural New Science, 1:2, 213-218.

Bart L. Weathington, Christopher J. L. Cunningham and David J. Pittenger. (2012). Understanding Business Research (1st Ed.). John W. \& Sons. Critical Values for the F max Test. 464.

Biabania, A., M. Hashemib and S. J. Herbert. (2008). Agronomic performance of two intercropped soybean cultivars. International Journal of plant production, 2:3, ISSN: 1735-6814.

Charles T. Dougherty. (1969). The influence of irrigation, row spacing, plant population and inoculation on the yield of soybeans in Canterbury, New Zealand Journal of Agricultural Research, 12:2, 367-380, DOI: 10.1080/00288233.1969.10421188.

CIMMYT (International maize and wheat improvement center). (1988). From agronomic data to farmers recommendations. An economics training manual. Completely revised ED. CIMMYT, Mexico, D. F., Mexico. 79.

CSA (Central Statistical Agency). (2017). Annual report on area and production of major crops. Addis Ababa, Ethiopia. 
De Bruin, J. L. and P. Pedersen. (2008). Soybean seed yield response to planting date and seeding rate. In: The Upper Midwest. Agronomy Journal, 100:3, 696-703. doi:10.2134/agronj2007.0115.

Gomez, K. A. and Gomez, A. A. (1984). Statistical procedures for agricultural research (2ndEd). John, W. and Sons, New York, 680.

Hassan, A. A. A. (2015). Study of some herbicides and plant density on the growth and soybean yield. Research Journal of Pharmaceutical, Biological and Chemical sciences: 6:1, 0975-8585, 115-126.

Iita (International institute of Tropical Agriculture). (1992). Sustainable food production in sub-Saharan Africa. Iita's contribution. Ibadan, Nigeria.208.

Ita. (1993). Archival report (1988-1992), Soybean Biological Nitrogen Fixation. Crop Improvement Division, Grain Legume Improvement Program part III. International institute of tropical agriculture, 10.

Lee, C. D., D. B. Egli and D. M. Tekrony. (2008). Soybean Response to Plant Population at Early and Late Planting Dates in the Mid-South. Agronomy Journal, 100, 971-976.

Leyla, G., B. Halil, EL. S. Ayman and A. Halis. (2017). Soybeans managing for maximize production: plant population density effects on seed yield and some agronomical traits in main cropped soybean production. https://www.researchgate.net/publication/315116894/DOI: 10.18006/2017.5 (1).031.037.

Mekonnen Hailu and Kaleb Kelemu. (2014). Trends in Soybean Trade in Ethiopia Technical report. Addis Ababa, Ethiopia. Research Journal of Agriculture and Environmental Management, 3:9, 477-484.

Mohammed Worku and Tessema Astatkie. (2011). Row and plant spacing effects on yield and yield components of soybean varieties under hot humid tropical environment of Ethiopia, Journal of Agronomy and Crop Science, 197: 67-74. OI: 10.1111/j.1439-037X.2010.00441.

Moshiur Rahman, Md., Md. Mosharrof Hossain, Md. Pravez Anwar and Abdul Shukor Juraimi. (2011). Plant density influence on yield and nutritional quality of soybean seed. Asian Journal of Plant science, 10: 2, 125132, DOI:10.3923/ajps.2011.125.123.

Ohyama T., R. Minagawa, S. Ishikawa, M. Yamamoto, N. Van Phi Hung, N. Ohtake, K. Sueyoshi, T. Sato, Y. Nagumo and Y. Takahasi. (2013). Soybean seed production and nitrogen nutrition. In: Board J. (Ed.), a comprehensive survey of international soybean research genetics, physiology, agronomy and nitrogen relationships, in tech, DOI: $10.5772 / 52287$.

Osei, S. K. and C. L. Norman. (1980). The effect of different row spacing and plant arrangements on soybeans. Can. J. Plant Sci. 60: 227-231, https://doi.org/10.4141/cjps80-031.

Rahman, MM., MG. Mwakangwale, JG. Hampton and MJ. Hill. (2005). Plant density affects soybean seed quality. Seed science and technology, 33:2, 521-525.

Saitoh, K. (2011). Effects of row spacing and planting density on podding and yield performance of early soybean cultivar "Enrei" with reference to raceme order. Soybean. Hany A. El-Shemy, (Ed.). Agricultural and Biological Sciences. Soybean Physiology and Biochemistry. 275-288. DOI: 10.5772/19025.

SAS Institute. (2001). Statistical Analysis Software (SAS) user's guide for personal computers. Version 9.0. SAS Institute, Inc., Cary, North Carolina. USA. 1028.

Sevgi, C., K. Mehmet and E. C. Mehmet. (2007). The effects of row spacing on yield and yield components of full season and double-cropped soybean, Turk. Journal of Agriculture, 31:147-154.

William. J. Cox and Jerome H. Cherney. (2011). Growth and yield responses of soybean to row spacing and seeding rates. Agronomy Journal, 103:1, 123-128.

Young, K. K., T. K. Hyun, K. C. Nam and C. K. Yeong. (2001). Effects of planting date and plant density on yield and yield quality of soybean forage in Jeju, Korea. Journal of crop science. 42:2, 95-99.

Zaimoglu, B., H. H. Arioglu and M. Aslan. (2004). Effects of seed quality on plant populations and seed yield of double cropped soybean in the Mediterranean region of Turkey. Asian Journal of plant sciences. 3: 574-577. DOI: $10.39 \mathrm{ss} 3 /$ ajps.2004.574.577. 